\title{
Association and Path Analysis of Yield and Yield Components in the RIL Population of Vigna radiata $\times$ Vigna umbellata
}

M. Kanimoli Mathivathana ${ }^{1}$, S.M. Samyuktha ${ }^{1}$, R. Deepa Priya ${ }^{1}$, I. Mariyammal ${ }^{1}$, P. Bharathi ${ }^{1}$, N. Jagadeeshselvam ${ }^{2}$, A. Karthikeyan ${ }^{2}$, M. Sudha ${ }^{2}$, M. Pandiyan ${ }^{4}$, G. Karthikeyan ${ }^{5}$, C. Vanniarajan ${ }^{1}$, M. Raveendran ${ }^{2}$ and N. Senthil ${ }^{2 *}$

${ }^{1}$ Department of Plant Breeding and Genetics, ${ }^{3}$ Department of Biotechnology, Agricultural College and Research Institute, Madurai, Tamil Nadu Agricultural University, Tamil Nadu, India

${ }^{2}$ Department of Plant Biotechnology, Center for Plant Molecular Biology and Biotechnology, Tamil Nadu Agricultural university, Coimbatore, Tamil Nadu, India ${ }^{4}$ Agricultural College and Research Institute, Tamil Nadu Agricultural University, Eachangkottai, Tamil Nadu, India

${ }^{5}$ Department of Plant Pathology, Center for Plant Protection Studies, Tamil Nadu Agricultural University, Coimbatore, Tamil Nadu, India

*Corresponding author

The experimental material was consisting of 108 RILs derived from a cross of VRM (Gg) $1 \times$ TNAU RED. The experiment was laid out in Randomised

Keywords

Association analysis,

Mungbean, Path analysis

Article Info

Accepted:

10 March 2018

Available Online: 10 April 2018 Complete Block Design with 3 replications. The observations were recorded on five randomly taken plants for six quantitative traits viz. days to fifty percent flowering (DFFW), plant height (PH), number of clusters per plant (NCP), number of pods per plant (NPP), hundred seed weight (HSW) and grain yield (GY) to estimate the correlation and path analysis. The correlation revealed that the grain yield had positive and significant association with number of pods per plant (0.77) and number of clusters per plant (0.48). Path analysis showed that the moderate negative direct effect was exhibited by number of clusters per plant (-0.218) followed by the low positive direct effect by hundred seed weight $(0.132)$ and days to fifty percent flowering (0.125). Hence, combined results of correlation coefficient and path analysis emphasis that number of pods per plant are major component traits for the improvement of grain yield. 


\section{Introduction}

The mungbean [Vigna radiata (L.) Wilczek], also known as green gram belongs to family Fabaceae and is native of India and Central Asia. It is a self-pollinated diploid plant with $2 \mathrm{n}=22$, having a drastic source of carbohydrates $(51 \%)$, protein $(24 \%-26 \%)$, minerals (4\%), and vitamins (3\%) (Karthikeyan et al., 2014). Their roots fix atmospheric nitrogen through symbiosis with nitrogen-fixing Rhizobium and Bradyrhizobium bacteria that in turn improves the soil quality (Yaqub et al., 2010). In the total cultivable area of about 6 million hectares (Nair et al., 2013), is occupied by mungbean. Although numbers of varieties have been recommended for cultivation, the productivity in the country is still low and there is a need for yield improvement (Narasimhulu et al., 2013). Therefore, improvement in grain yield remains the most important breeding objective in mungbean. Yield is a polygenic trait and is influenced by several other traits that affect seed yield (2007). Srivastava and Singh (2012) reported that yield is correlated with various yield contributing traits that are inter-related. These traits are associated to each other and with seed yield either positively or negatively. The quantitative characters are the best indicators of yield. Yield is a complex character which is affected by a number of component characters and the surrounding environments. Therefore, selection for grain yield becomes difficult unless the associations between yield contributing characters are known. Correlation and path analysis are important biometrical tools for getting information regarding interrelationship among various traits for use in selection programme. Correlation coefficient estimates the joint relationship among various plant traits, while path analysis estimates the magnitude of direct and indirect effects on seed yield and yield contributing traits. The path analysis evaluates the key traits for the genetic enhancement in yield. Hence evaluation of different traits that are correlated with seed yield is of great importance. On each plant, number of pods per plant is positively correlated with grain yield in mungbean. Hence, considering these points, the present investigation is aimed at estimating the correlation coefficients and direct as well as indirect effects of a number of yield components in the recombinant inbred lines (RILs) population of Vigna radiata $\times$ Vigna umbellata.

\section{Materials and Methods}

The $\mathrm{F}_{9}$ derived 108 recombinant inbred line (RIL) population obtained from the cross of $\operatorname{VRM}(\mathrm{Gg}) 1(V$. radiata $) \times$ TNAU RED $(V$. umbellata) was used to identify the important yield attributing traits by correlation and path analysis. The RILs were planted in Randomized Complete Block Design during Rabi, 2017 at Agricultural Research Station (ARS), Tamil Nadu Agricultural University, Virinjipuram. The RILs were grown in a row of $3 \mathrm{~m}$ length (accommodating 25 plants) with 3 replications and the plant to plant spacing between and within rows was kept $30 \mathrm{~cm}$ and $10 \mathrm{~cm}$ respectively. All the recommended agronomic practices were carried out during the crop growth period. The observations were recorded in 5 randomly selected plants for six different traits viz., Days to fifty percent flowering, plant height, number of clusters per plant, number of pods per plant, hundred seed weight and grain yield. The mean values were used for estimating correlation and path analysis according to Dewey and Lu (1959). Correlation and path analysis were performed using TNAUSTAT (Manivannan, 2014).

\section{Results and Discussion}

Correlation coefficient analysis depicts the degree and extent of relationship among important plant traits and it provides basic 
criteria for selection. In the present study, number of clusters per plant and number of pods per plant exhibited highly significant and positive association with grain yield (Table 1).

The significant association of number of clusters per plant with grain yield has also been reported by Reddy et al., (2011), Hemavathy et al., (2015), Pinchhyo et al., (2016) and Keerthiga et al., (2018).

The significant correlation between numbers of pods per plant with grain yield has been reported by Reddy et al., (2011), Hemavathy et al., (2015), Pinchhyo et al., (2016), Dhoot et al., (2017) and Keerthiga et al., (2018). The yield improvement in mungbean can be accomplished by the selection of parents with these traits.
Correlation among the component characters revealed that the plant height showed significant positive correlation with hundred seed weight. The association of plant height to hundred seed weight was similar to the findings of Keerthiga et al., (2018). On contrary the negative correlation of plant height with hundred seed eight was reported by Narasimhulu et al., (2013). The partitioning of assimilates decides production of either better vegetative or reproductive part in a plant. The number of clusters per plant exhibited highly significant association with number of pods per plant. The similar findings were displayed by Narasimhulu et al., (2013), Dhoot et al., (2017), Keerthiga et al., (2018). Since the pods are produced in clusters, the increase in number of clusters automatically increases the number of pods per plant.

Table.1 Simple correlation coefficients among the 14 quantitative characters in mungbean

\begin{tabular}{|l|r|r|r|r|r|r|}
\hline Characters & DFFW & \multicolumn{1}{|c|}{ PH } & NCP & NPP & HSW & GY \\
\hline DFFW & 1 & & & & & \\
\hline PH & -0.16 & 1 & & & & \\
\hline NCP & 0.02 & 0.10 & 1 & & & \\
\hline NPP & 0.01 & 0.10 & $0.67 * *$ & 1 & & \\
\hline HSW & -0.07 & $0.21 *$ & 0.14 & 0.08 & 1 & \\
\hline GY & 0.12 & 0.01 & $0.48^{* *}$ & $0.77 * *$ & 0.14 & 1 \\
\hline
\end{tabular}

**-Significant at 1.0 per cent level of significance *-Significant at 5.0 per cent level of significance DFFW = Days to fifty percent flowering; PH = Plant height; NCP = Number of cluster per plant; NPP = Number of pod per plant; HSW = Hundred seed weight; GY = Grain Yield

Table.2 Direct and indirect effect of component characters on grain yield as revealed from path analysis

\begin{tabular}{|l|l|l|l|l|l|}
\hline Characters & DFFW & PH & NCP & NPP & HSW \\
\hline DFFW & $\mathbf{0 . 1 2 5}(\mathbf{L})$ & 0.012 & -0.002 & 0.007 & -0.009 \\
\hline PH & -0.020 & $\mathbf{- 0 . 0 7 5}$ & -0.027 & $0.107(\mathrm{~L})$ & 0.032 \\
\hline NCP & 0.001 & -0.009 & $\mathbf{- 0 . 2 1 8}(\mathbf{M})$ & 0.875 & 0.024 \\
\hline NPP & 0.001 & -0.008 & $-0.188(\mathrm{~L})$ & $\mathbf{1 . 0 1 4}$ & 0.012 \\
\hline HSW & -0.009 & -0.018 & -0.039 & 0.096 & $\mathbf{0 . 1 3 2}(\mathbf{L})$ \\
\hline
\end{tabular}

DFFW = Days to fifty percent flowering; PH = Plant height; NCP = Number of cluster per plant; NPP = Number of pod per plant; HSW = Hundred seed weight 
However the nature of association is often incomplete in case of correlation analysis alone. Hence the path coefficient analysis is accomplished to quantify the interrelationship of different components and their direct and indirect effects on seed yield. Path analysis showed that the moderate negative direct effect was contributed by number of clusters per plant $(-0.218)$ followed by the low positive direct effect by hundred seed weight (0.132) and days to $50 \%$ flowering (0.125) (Table 2). The similar result for number of cluster per plant was showed by (2014). Tabasum et al., (2010) and Das and Barua (2015) reported similar results for hundred seed weight and days to $50 \%$ flowering.

Among the component traits studied, the low positive indirect effect on yield was exhibited by plant height via number of pods per plant (0.107). This result was in correspondence with finding made by Garje et al., (2014). The low negative indirect effect by number of pods per plant is via number of clusters per plant (-0.188). Tabasum et al., (2010) reported the moderate negative indirect effect by number of pods per plant via number of clusters per plant. These results indicate that the indirect selection for grain yield can be made through number of pods per plant. From the correlation and path analysis the present investigation depicts that the trait number of pods per plant was found to be important yield attributing trait since it showed positive low direct effect and highly significant positive association with grain yield.

\section{References}

Das, R.T. and P.K. Barua. 2015. Association Studies for Yield and its components in Green Gram. International Journal of Agriculture, Environment and Biotechnology, 8(3): 561.

Dewey D.R., K.H. Lu. 1959. A correlation and path coefficient analysis of components of crested wheat grass seed production. Agronomy Journal, 51: 515-518.

Dhoot, R., K.G. Modha., D. Kumar and M. Dhoot. 2017. Correlations and Path Analysis Studies on Yield and its Components in Mungbean (Vigna radiata (L.) Wilczek). Int. J. Curr. Microbiol. App. Sci, 6(5): 370-378.

Garje, U.A., M.S. Bhailume, M.S., Nagawade, D.R. and Parhe, S.D., 2014. Genetic association and path coefficient analysis in green gram [Vigna radiata (L.) Wilczek]. J. Food Leg, 27(2):151154.

Hemavathy, A.T., N. Shunmugavalli and G. Anand. 2015. Genetic variability, correlation and path co-efficient studies on yield and its components in mungbean [Vigna radiata (L.) Wilezek]. Legume Res, 38(4): 442-446.

Karthikeyan, A., V.G. Shobhana, M. Sudha, M. Raveendran, N. Senthil, M. Pandiyan and P. Nagarajan. 2014. Mungbean yellow mosaic virus (MYMV): a threat to green gram (Vigna radiata) production in Asia. Int. J. Pest Manag., 60: 314-324.

Keerthiga, S., S. Sen., H.R. Pandya and K.G. Modha. 2018. Correlation and Path Analysis in $\mathrm{F}_{4}$ Progenies of Green Gram [Vigna radiata (L.) R. Wilczek] for Seed Yield and its Attributes. Int. J. Curr. Microbiol. App. Sci, 7(1): 710719.

Manivannan, N., 2014. TNAUSTATStatistical package. Retrived from https://sites. google. com/site/tnaustat.

Nair, R. M., Yang, R. Y., Easdown, W. J., Thavarajah, D., Thavarajah, P., Hughes, J. d'A., et al., (2013). Biofortification of mungbean (Vigna radiata) as a whole food to enhance human health. J. Sci. Food Agric. 93, 1805-1813.

Narasimhulu, R., N.V. Naidu., P. Shanthi., V. Rajarajeswari and K.H.P. Reddy. 2013. 
Genetic variability and association studies for yield attributes in mungbean (Vigna radiata $\mathrm{L}$. Wilczek). Indian $J$. Plant Sci, 2(3): 82-86.

Pinchhyo, B. G.M. Lal and T. Neha. 2016. Studies on genetic variability, correlation and path analysis in greengram (Vigna radiata L. Wilczek) germplasm. International Journal of Agriculture Sciences, 8(51): 2267-2272.

Reddy, D., R. Kodanda, O. Venkateswarlu, M.C. Obaiah and S.G.L. Jyothi. 2011. Studies on genetic variability, character association and path co-efficient analysis in green gram. Legume Res., 34 (3): $202-206$.

Shivanna, J., C. S. Ravi and B. S. Sreeramu. 2007. Character association and path coefficient analysis among economic traits in Makoi (Solanum nigrum L.). Karnataka J. Agr. Sci., 20: 575-577.

Srivastava, R. L. and G. Singh. 2012. Genetic variability, correlation and path analysis in mungbean (Vigna radiata $\mathrm{L}$. Wilczek). Indian J. L. Sci., 2: 61-65

Tabasum, A., M. Saleem and I. Aziz. 2010. Genetic variability, trait association and path analysis of yield and yield components in mungbean (Vigna radiata (L.) Wilczek). Pak. J. Bot, 42(6): 3915-3924.

Yaqub, M., T. Mahmood, M. Akhtar, M.M. Iqbal and S. Ali. 2010. Introduction of mungbean (Vigna radiata (L.) Wilczek) as a grain legume in the annual ricewheat double cropping system. Pak. J. Bot., 42: 3125-3135.

\section{How to cite this article:}

Kanimoli Mathivathana, M., S.M. Samyuktha, R. Deepa Priya, I. Mariyammal, P. Bharathi, N. Jagadeeshselvam, A. Karthikeyan, M. Sudha, M. Pandiyan, G. Karthikeyan, C. Vanniarajan, M. Raveendran and Senthil, N. 2018. Association and Path Analysis of Yield and Yield Components in the RIL Population of Vigna radiata $\times$ Vigna umbellata. Int.J.Curr.Microbiol.App.Sci. 7(04): 1231-1235. doi: https://doi.org/10.20546/ijcmas.2018.704.137 